\title{
Learning through Participation
}

\section{Paradigms of Civic Learning among Chinese University Students in the Age of Social Media}

\author{
LINKe | ORCID: 0000-0002-9065-0490 \\ Faculty of Education, Beijing Normal University, Beijing, China PR \\ linke@bnu.edu.cn
}

\begin{abstract}
Social media play increasingly important roles in changing young people's learning styles. The most significant implication for moral and citizenship education would be that young people nowadays are employing social media for cybercivic participation and learning, constructing to both online and offline communities. This paper, based on a virtual ethnographic study, examines how Chinese university students participate in civic discussions and activities by the use of online forums and social network sites. It further explores youth capabilities of learning to be responsible, reciprocal, and reflective citizens. The paper presents three potential learning paradigms, namely dutiful, actualising, and reflective cybercivic learning, and argues that each paradigm has its advantages and limitations in developing moral and civic knowledge, values, and skills. To integrate three learning paradigms into the institutional education system would be an innovation of moral and citizenship education in the age of social media.
\end{abstract}

\section{Keywords}

cybercivic learning - cybercivic participation - citizenship education - media literacy education - social media

\section{Introduction}

Social media play increasingly important roles in changing learning styles in many disciplines, as they encourage more interactive, participatory, and collective learning patterns through internet-based applications and services 
(Langmia, Tyree, O'Brien, \& Sturgis, 2014). A considerable question for moral and citizenship education is whether social media can promote students learning citizenship in a changing world (Bennett, 2008a). It has been emerging in many countries that young people are using social media to participate in civic affairs. Not only they transform traditional democracy represented by voting, governing, demonstrating, and protesting, but also create new forms of civic engagement represented by online discussion, assembling, volunteering, petitioning, and boycotting (Bennett, 2008b; Banaji \& Buckingham, 2010; Loader, Vromen, \& Xenos, 2014; Wells, 2015). The combination of internet usage and civic engagement has also been reported in China. On the one hand, networked citizens are developing their awareness of subjectivity, rights, responsibilities, national identities and citizenship, and gradually influencing the social, political and educational atmosphere through online debates, votes, polls, and donations. On the other hand, they are inevitably involved in fanatical activities and ideologies, such as online hype, network spoof, cyber violence, populism, and the abuse of democracy in some cyber communities (Dong \& Han, 2008; Fang, 2011; Qi, 2011; Sun, 2013; Chen, 2015). Although there is a wide-ranging body of literature reporting the trend of youth civic participation happened in cyberspace, few studies have made a thick description of how young people can be benefited from social-media-based civic participation, meanwhile, contribute to online and offline communities. Thus, I undertook empirical research to explore a group of Chinese university students' living experience of cybercivic participation. This paper reports a part of the research findings and focuses on implications for education.

In the study, I introduce a notion of cybercivic learning to describe the process of learning through cybercivic participation. The word of "civic" has abundant meanings, while I consider its origin from "the public sphere" (Habermas, 1974 [1964]) which is a domain of social life where public opinions can be formed through rational communication and critical debates, referring both individual freedoms and citizens' duties to public welfare. In this sense, I employ the concept of "civic participation" summarised by Bennett et al. (2006) as citizens' open debates or activities that occur in a public sphere, particularly relating to political and social dimensions. What I mean by "cybercivic participation" denotes a way of revitalizing civic life stimulated in cyberspace which focuses on citizens' use of social media for discussing and solving public affairs. The study indicates that young people take cybercivic participation as an opportunity for civic learning and community involvement, which can be recognised as "cybercivic learning". Unlike the traditional civic learning approaches that rely on fixed curricula, assigned textbooks, and instructions given by teachers in the classroom, cybercivic learning encourages learners to integrate formal and informal learning modes. It aims to equip learners with civic knowledge, 
values and skills for their online practice and living experience so that they make positive contributions to a virtual community and a real society.

To understand and analyse youth cybercivic learning in detail, I applied virtual ethnography (Hine, 2000) for the study, which is a recently developing methodology appropriate for online fieldwork and virtual community exploration. Hine (2000) argues that "rather than the technology itself being an agent of change, uses and understandings of the technology are central" (p. 4). Therefore, she highlighted that the construction of a virtual community depends on its members' sense of responsibilities, intimate connections, and authenticity and reliability. However, the existence of multiple identities makes a looser and more flexible virtual community because every user can play different roles synchronously or asynchronously (Hine, 200o). For this reason, a virtual ethnographic study needs to consider both online and offline interactions among the community members. Applying research methods of online participant observation and offline in-depth interviews, I collected data and shared stories that emanate from events in the fields that constitute the youth cyber community. The study took both opportunity sampling and snowball sampling strategies to select a target group of 18-24-year-old Chinese university students. The field sites for continuous observation during the year 2012-2016 were two public online forums (OFS) and two social network sites (SNSs) which are very popular among sample students (see Table 1). The interviews were conducted

TABLE 1 The Categories and Features of Websites for Observation

Examples $\quad$ Features

OFS BYC

<http://bbs.youth.cn/

forum.php>

ChickenRun

(a university forum)

$<$ The web link is disguised

for privacy protection for

a group of students $>$

SNSs Renren

(Chinese Facebook)

$<$ www.renren.com $>$

Sina Weibo

(Chinese Twitter)

$<$ http://weibo.com>
A top-down forum: built, sponsored, and operated

by the Communist Youth League Centre, to serve young people

A bottom-up forum: built, sponsored, and operated by university students

A Chinese social networking service based on widespread social relationships such as alumni networks, friendship, and partnership A Chinese micro-blogging site where users read, write and disseminate short messages to/from the public or among a particular circle of contacts 
in a face-to-face and semi-structured way, with 55 participants in six universities, including 47 student interviewees (SI) and 8 teacher interviewees (TI). In terms of data analysis, I applied the approaches of qualitative content analysis (Schreier, 2012) to systematically describe youth cybercivic participation happening in virtual communities and to interpret the social, political, cultural, and educational significance of their participation.

The main body of the paper contains six sections. This first section introduces key concepts and research methods applied for the study. The second section draws on relevant theories and Lance W. Bennett's two paradigms of citizenship to analyse Chinese students' cybercivic participation. Based on the existing theoretical framework, the study reports three paradigms of cybercivic learning in the following sections, including dutiful cybercivic learning $(D C L)$, actualising cybercivic learning $(A C L)$, and reflective cybercivic learning $(R C L)$. Finally, the conclusion summarises a set of learning elements of each paradigm and discusses the educational possibility of preparing young people to be cybercivic citizens.

\section{Theoretical Frameworks of Civic Participation and Civic Learning}

\subsection{Multiple Levels of Civic Participation and Civic Learning}

Civic participation has been recognised as one of the important pedagogical approaches since the advocacy for participatory democracy. As Pateman (1970) argued, citizens can learn from their own experiences of engaging in social and political activities, which provide them with opportunities to understand and exercise democratic procedures at different levels, such as family, school, local community and state, and then to commonly negotiate and test different approaches for problem-solving and policy-making. This whole process is not only political practice but also educational practice advancing citizens' awareness and abilities of civic participation.

Scholars have discussed different types, dimensions and extents of civic participation, which consequently conduce to multiple levels of civic learning and citizenship. Arthur, Davies, and Hahn (2008) have argued that young people are transforming their participating interests away from formal domains (e.g. political parties, government concerns and public protests) towards informal domains (e.g. NGOs, charities, volunteering, environmental protection and cultural modes of expression). Pérez Expósito (2013) divided young people into a disengaged group and an engaged group. The former group were seen as politically apathetic and civically incapable, while the latter as being keen on political activities that are the core of civic participation. He stressed that the 
so-called "disengaged group" might not be completely indifference, rather, they just shifted their political interests into social or cultural activities. Therefore, he suggested integrating formal and informal domains, resources and opportunities in order to provide young people with a diverse and dynamic process of civic learning.

Another binary formulation is that of good citizens and active citizens (QCA, 1998; Crick \& Lockyer, 2010). Good citizens tend to obey the law, respect authority, be polite and well-behaved, address moral virtues of care and concern for others, be good neighbours and generally relegate ideas of the good life in private spheres (Crick \& Lockyer, 2010). By contrast, active citizens emphasise reflective capacities and responsible behaviours to the community. As defined in the national curriculum for England, active citizens are those who are "willing, able and equipped to have an influence in public life and with the critical capacities to weigh evidence before speaking and acting" (QCA, 1998, p. 7). The process of nurturing active citizens is helpful to construct and sustain social solidarity (Blunkett \& Taylor, 2010; Crick \& Lockyer, 2010). Although this notion has often been criticised for it may trigger challenges to the authority, it has been regarded in many cases as an ideal goal of citizenship education (Ireland, Kerr, Lopes, Nelson, \& Cleaver, 2006; Ross, 2008).

Hudson (2005) offered an improved three-level citizen identity framework including passive, active and politicised citizens. The passive ones are not as enthusiastically engaged in civic activities as the active who believe they can make a difference but lack of strategies. Significantly, some young people move beyond active levels, as they not only take part in school-based and local activities with a strong sense of responsibility and concern, but also critically reflect on their participation experience with a politicised perspective, with the use of relevant political knowledge and skills (Osler, 2000; Hudson, 2005). In Hudson's framework, the quality of civic learning not only depends on the frequency and range of active participation but also the depth of citizens' reflections from deliberative political perspectives. In short, the highest level of civic learning leads to citizens' capacities of rational reflection, critical thinking and creative contribution.

Some of the above concepts have been also found in the context of China, though their connotations may be different due to political, social and cultural differences. For instance, there is a category described as insouciant bystanders who are citizens holding a national status, but they do not feel solidarity with their fellows, nor are they concerned to protect human rights in practice (Lin \& Starkey, 2014). Insouciance here means more than disinterest, unconcern, or nonchalance, while the bystanders have a minimalist understanding of what is entailed by citizenship (Osler and Starkey, 2005). The concept of "good citizens" 
in China has much more comprehensive meanings and powerful influence than others. It is praised for citizens' loyalty to the motherland, to the Communist Party of China (CPC) and to Chinese people. It also contains citizens' submissive behaviours, social and moral commitments, and reflections on personal virtues to become nice and polite people (Print \& Tan, 2015). Thus, Chinese education aims to produce such "good citizens" with an emphasis on moral, political and ideological principles (Lee \& Ho, 2008). The CPC defines the outcomes of Chinese citizenship and moral education programmes as "qualified socialist citizens". In other words, qualified good citizens should adhere to "citizenship and socialist concepts of democracy, the rule of law, freedom, equality, equity and justice" (MOEPRC, 2010, p. 10). There is little expectation that good citizens will apply critical faculties to the state of democracy or the application of justice, hence the linguistic notion of active citizens is seldom used in Chinese officially political discourse. However, its elements of moral commitment and social responsibility are highlighted expected in China.

\subsection{Paradigms of Online Citizenship and Civic Learning}

Considering the change of citizenship and civic learning in a post-industrial age dominated by digital media and the Internet, Bennett's team have proposed two paradigms of citizenship and relevant approaches of civic learning, which address participating and learning opportunities in various online and offline settings (Bennett, 2008b, 2008a; Bennett, Wells, \& Rank, 2009). The selfactualizing citizen (AC) is a recent citizenship paradigm featured with interactive and peer-sharing activities through digital media across loose networks, such as friendship-based community, interest groups and consumer groups. AC holds a weak sense of duty to participate in government-related political issues, but it focuses on "life-style politics" (Giddens 1991), ranging from moral concerns, political consumerism to environmental quality. By contrast, the dutiful citizen (DC) usually pays attention to "institutional politics" (Putnam, 200o) represented by issues of government, parties and voting. DC relies more on "the hierarchical membership" in political parties, defined social groups, public organisations and institutions, and gets used to communicating through traditional media like newspaper and TV (Bennett, 2008a, p. 14; Bennett, Freelon, \& Wells, 2010, p. 398).

AC and DC respectively lead to two styles of civic learning (see Table 2). The actualising civic learning (ACL) is favoured and developed by young people as it emphasises autonomy or peer control and problem-solving (Coleman, 2008). Meanwhile, the dutiful civic learning (DCL) learning seems more like the one-way delivering of conventional and institutional knowledge and skills. 
AC civic learning styles

Interactive information and

knowledge:

- project-based

- shared by peer-to-peer networks

Training participatory skills of:

- expression ideas by the use of self-produced media

- media creation

Preference for learning in self-defined and democratic environments

Actions or activities generated by peers

Assessing by learners
DC civic learning styles

Authoritative information and

knowledge:

- text-based

- provided by governments, teachers, news reports

Training passive skills of:

- transmission information by the use of traditional forms of public address

- media consumption

Preference for learning in site-defined and structured organisations

Actions or activities offered by authorities

Assessing by external standards

SOURCE: BENNETT ET AL. (2009, P. 108); BENNETT ET AL. (2010, P. 49)

Although the ACL becomes increasingly popular, Bennett finds that the DCL upholding a set of structuralised learning contents, methods and assessments still plays influential roles. Nevertheless, the boundary between ACL and DCL is not too strict to be crossed. Young people may be able to benefit from the integration of two styles (Bennett et al., 2009).

By use of existing theories to interpret empirical data, this study has found different styles of citizenship, civic participation and civic learning among the observed and interviewed Chinese university students. The following sections will report and discuss key research findings.

The first mode is dutiful cybercivic learning $(D C L)$. It can be defined as a process of social-media-based learning to be good citizens or dutiful citizens who become familiar with external normative standards formatted by authorities. DCL focuses on connecting participants with institutional civic issues arising 
from social or political news, public policies, government developments, innovations of the Parties, concerns with the state legal system and the moral commitments of citizens. In this research, the investigated DCL primarily takes place through the following three methods.

\subsection{Subscribing to Mainstreamed News Feeds}

News reading is one of the effective approaches for citizens to learn about their local, national or international communities. A great number of students reported that mainstreamed news representing authoritative perspectives can be customised and delivered to them by news subscription. They no longer intentionally access news through traditional media, such as newspapers, radio, television programmes or conventional read-only websites. Instead, they have become accustomed to using social media to obtain the latest eyecatching news and to get familiar with the society immediately. Many of them cannot help logging in Weibo every few hours to check the updates. As the students described, "daily headlines along with popular social, political, entertainment news would be automatically shown on the homepage", "highlighted in a pop-up window", or "full of personal message boxes" (SI 23, 24 \& 29). Looking through the subscribed news, students feel that they are fed with information and public opinions; while forwarding and sharing the news, they also feed others in wider online networks.

The students understand that the default News Feeds are selected and promoted by social media companies mainly for commercial and political purposes. However, they believe news with professional and administrative intervention would be relatively reliable and trustable. They agreed that "the pop-up window as a summary of breaking news must be selected and produced by professional website editors" (SI 24) or "in accordance with laws and regulations" (SI 28). They also found that "the texts and tones of sNs newsletters are usually close to the news reports by mainstream media like newspaper or television" which more or less "represent a kind of official perspective and attitude" (SI 29). For these students, to subscribed officially approved newsletters would help them to be closer to authoritative information and knowledge (Bennett et al., 2009).

When choosing news producers from Weibo, students tend to consider the reputation of the media outlets and the quality of their editors. They listed a number of factors that may influence the news producers they followed on Weibo, including "the provision of authentic facts", "detailed background information of news", "objective stand", "sharp and profound opinions" and "frequent and useful updates" (SI 2, 5, 42, 43 \& 44). These factors together define reliable and responsible information producers. Despite this, students were not 
always satisfied with the quality of News Feeds because it seems more like "fast-food news" providing "less context of information" and "blurry insights" (SI 2, 6 \& 19). In order to know detailed information, they turn to formatted announcements.

\subsection{Absorbing Formatted Announcements}

Absorbing announcements means that students not only read that kind of media text but also improve or re-produce the materials. For interviewed students, the term of announcement implies "information-rich", "trustable" and even "official", as it is usually published by a government, an authority, an organisation, by individual users who represent these institutional agents, or by people who produce structuralised pro-government and pro-social content (SI 2, 21, 25 \& 43). The official announcements come in different forms, such as the collection of mainstreamed news, completed texts or documents of policies, laws or regulations, and the explanations about public events from those authoritative organisations.

Top-down forums have distinct advantages for announcement-based learning because they exhibit detailed matters that can be stored and sorted for future access. Since BYC is a state-managed forum, students feel information published there is more reliable in terms of national civic activities. The study has summarised five main types of announcement posts observed on this site:

- news: selected and forwarded social and political news;

- projects: information about local and national civic projects (e.g. the West Volunteering Plan, University Graduates as Village-Officials, and the Rural Area Supporting Projects);

- policy: national policy publicity and relevant interpretation, such as case studies about the projects above;

- institutional knowledge: knowledge about the Party, the Chinese political system, law and regulations, military affairs, history and culture, and the civil service examination;

- peer experience: experience-sharing by successful volunteers, officials, and youth activists.

These posts provide students with both relevant and comprehensive information for this mode of dutiful cybercivic learning. Students who intended to apply for jobs as volunteers or village-officials and who prepared for civil service examinations admitted that they used to visit BYc. However, they seldom left comments on this top-down forum and they only visited this forum for collecting specific materials (sI 6, $21 \& 45$ ). Thus, BYC is more like an information centre for students. 
On bottom-up forums, students post authoritative materials and re-produce them to meet their own needs. Taking ChickenRun as an example, student users selected, sorted, edited and shared their understanding of national policies and regulations so that official requirements are localised, customised and more suitable for peer groups. There is a student-edited handbook published on ChickenRun, titled as Handbook of Public Service and Volunteering Work. It introduces basic information, knowledge, policies and experiences about different volunteering work, which is calling for student civic and social responsibility. In fact, the handbook was a collection of 54 posts contributed by student users and including ongoing updates from September 16, 2010 to February 23, 2014. This is a successful example that students work together to create knowledge and transfer official, institutional and formal civic knowledge (Arthur et al., 2008) into user-friendly and youth-accessible learning materials. This case indicates that DCL can be applied in an interactive approach, which is different from Bennett et al. (2009)'s findings.

\subsection{Studying Online Citizenship Courses}

The present research suggests that social media has already become an effective mechanism to expand the classroom-based curriculum for citizenship education and involvement in civic affairs. One of the typical citizenship courses is CPC Party Lectures [党课], which are a set of compulsory training courses along with examinations preparing for student candidates who apply for CPC membership. The observed university students often looked for study materials or shared their learning experiences on different social media: some asked their network friends about the time and schedule of the course; some asked existing members about their interests and motivations for joining the Party; some complained that the contents of the course were too difficult to understand and asked for help; and some shared their class notes and references for the examination. Although the online conversations among students focused upon information and material exchanges, this way of learning about CPC is more accessible for beginners who know little about the procedure to the Party.

Another example is the Massive Open Online Courses (Moocs). A series of overseas MOocs were introduced and translated to China in 2013. Those attractive courses along with their dialogical teaching strategies have stimulated university students' interests in a wide range of civic topics. A моос called 'Justice' provided by Harvard University is one of the most popular courses spread and discussed among the investigated students. For example, students were very interested in the 'trolley problem' mentioned in the course, concerning the trolley driver's choices when a train is out of control. It has been 
observed that students posted on Renren and ChickenRun to discuss such a conundrum, in which they found difficult to resolve the dilemma morally. They also put such a dilemma-based discussion into their life practice, thinking and negotiating how to allocate electricity and water resources to different regions in China and how to solve the air pollution in Beijing while not negatively affecting other cities. The engagement with such online courses creates a starting point for students to consider controversial issues which are vital for moral and citizenship learning.

Although DCL is featured with a responsibility-driven model with reliable information and well-organised knowledge, this style is criticised for being an indoctrination-driven system rather than communication-driven (Coleman, 2008). Thus, this learning paradigm might not be suitable for students who feel disengaged in formal or structured organisations and who fall further behind in civic awareness from those who take an active and continuing interest.

\section{Actualising Cybercivic Learning: an Interactive Paradigm}

The second mode, actualising cybercivic learning ( $A C L)$, primarily focuses on interest-driven activities related to students' everyday online interactions. It is also related to citizens' unintended and unexpected participation experience, which is one of the pre-conditions for building a democratic society where people have opportunities to hear of different opinions and to realise standpoints (Sunstein, 2001). ACL can also be recognised as a kind of hidden curriculum in cyber space for citizenship education helping learners to gradually acquire a wide range of information and collaboratively engage in public life.

\subsection{Learning from Lurking}

The majority of interviewed students reported the starting-point of their cybercivic learning would be through lurking, as they can easily access lots of information and hear different opinions but not necessarily make an expression. Moreover, lurking expanded their civic interests, inspiring them to further search or digest information that they may never have thought about otherwise. As students below said:

I had never heard of a group in China called 'the left behind Children' until I saw an article reporting their educational problems and calling attention to these children, whose parents migrate to big cities to earn their bread, but leave the children in rural areas living with grandparents or neighbours (SI 5). 
I'm a football fan. I used to think that the Chinese football team's poor performance was due to weak physical quality of football players and less effective training strategies. Yet, I started to realise a deeper institutional and administrative failure when I saw B BS threads about the corruption scandal of the Chinese Football Association (SI 43).

Although both students seldom responded to topics online, they admitted that their opinions and attitudes had been changed by reading a series of topics silently. SI 5 started to be concerned by and sympathetic to socio-economic disadvantaged groups, while sI 43 transferred his attention from purely sports issues to the political wrestling behind sports. These cases illustrate that students can form the bases of civic knowledge even though they just hang out online (Bachen, Raphael, Lynn, McKee, \& Philippi, 2008; Ito et al., 2010).

However, lurking does not always lead students to normative outlooks in relation to their civic awareness and knowledge, because of their exclusive and fragmented reading in the loose structures of the online community (Loader, 2007; Rheingold, 2012). As interviewed students noticed, the websites keep telling that "you probably like this" (SI 18), "your friends have viewed this" (SI 39) and "the celebrity who you follow just update a post" (SI 40). Sunstein (2001) describes this homogeneousness as information cocoons, where people stick to certain topics and believe what they see and what they like is the only truth, instead of exploring and exchanging a wider range of views. He reminds that homogeneous voices closing off alternative views would be harmful to cultivating informed citizens, even harmful to a democratic society.

\subsection{Learning from Networked Sharing}

Sharing represents the basic spirit of social media that benefits ACL. This study finds that students learn civic issues from networked sharing which includes two stages, namely sharing to learn and learning to share. For the former, the behaviour of sharing can stimulate self-expression for civic conversation in a public space. Students not only spread information like "job hunting advice" and "news of discount shopping" (SI 23 \& 25), but also to inform "particular audience with particular meanings" and to "arouse public interest and help people in need or contribute to the community" (SI 3 \& 4). An example provided by a teacher interviewee (TI) indicates that students widely share a notification and relevant policies about student loans and scholarships at different social media platforms, in order to help their peers in need. The teacher was pleased to see that "students are sharing and learning the value of reciprocity" 
(T1), which is one of the elements for democratic citizenship (Osler \& Starkey, 2005). Through networked sharing, students strengthen beliefs about mutual help and cooperation, which helps them better accommodate their local community.

In the latter stage of sharing, students start to realise smarter ways of sharing and the importance of critical thinking. They gradually learn to identify authentic and valuable information from their daily sharing experiences. Also, they pay attention to the copyright of online materials. For instance, one student highlighted "a moderate sharing". She further explained that "I prefer to just share something verified to be Kaopu [靠谱] "(SI 16), which is a Chinese colloquial word referring to reliable and responsible. The other suggested, "tracking back to original copyright is sometimes a good way to test whether the resource is reliable or not" (SI 21).

The limitations of sharing for cybercivic learning needs to be further discussed. For one thing, general information-sharing may focus exclusively on personalised interests instead of upon public and civic issues (Livingstone, Bober, \& Helsper, 2005). For another, the crisis of collective polarisation may negatively influence the quality of civic discussion, as a group of people move toward a more extreme and radical point of views based on homogeneous information-sharing and the members' predeliberation tendency (Sunstein, 2001). In order to guide students for better sharing, exchanging electronic information has been proposed as one of the nine themes of digital citizenship for student learning in the USA (Ribble \& Bailey, 2011). This reminds us of a need to integrate formal citizenship education and ACL.

\subsection{Lifestyle Political Discussing}

The phrase of lifestyle politics (Giddens, 1991) refers to the politics of life decisions in the process of self-actualisation, which involves a broad range of issues related to families, friends, workmates, consumption, entertainment, environment and so on. These non-party political issues can also encompass active interests and concerns relating to the local community.

Lifestyle political discussing has been found in this study as a distinct feature of youth cybercivic participation. Outwardly, students favour discussing leisure and cultural topics. However, they are not politically apathetic but only disengaged from mainstream political discourses and activities (Loader et al., 2014). The investigated students have reported that they pay attention to online topics of volunteering, charity fundraising events, celebrity interventions, and environmental movements. They are acquiring more practical knowledge of civic affairs and developing skills and values for living in a community. This includes personalised and fragmental political and social insights, in 
contrast to structured knowledge provided by authorities, mainstream media or university curricula. For example, several observed and interviewed female students liked online shopping and usually talked about shopping-related issues on their university forums. At the beginning, their conversation focused on "what brands of clothes and cosmetics are on sale" or "how to get more discount or vouchers" (SI 2, $4 \& 5$ ). When they found that some student sellers were selling products for particular charity purposes, they were more likely to buy these products to help blind and deaf-mute children or help children whose parents are in prison. As they talked with sellers and other buyers online, they got to know:

- what special care the disadvantaged children need;

- what policies and conditions should follow for charity selling online;

- how a charity organisation worked;

- how an ordinary student can open a charity shop online;

- what difficulties an online charity seller may encounter.

They admitted that such a discussing and purchasing process helps them better understand the online charity bazaar, gaining both official and non-official knowledge about the disadvantaged groups. Moreover, students prefer to use relatively loose and flexible patterns of online expression. This is a new literacy of digital citizenship emphasising on the awareness and ability to respect others and inclusively and tolerantly respond to different voices (Selwyn, 2002; Loader et al., 2014).

Some university tutors have realised "the educational significance of the real-life problems" and suggested that tutors should join student online and offline discussions in order to help students for in-depth cybercivic learning.

Every kind of lifestyle problem that students meet and talk about online could be an opportunity for them to learn about the society...Education should not always be done in a serious, rigorous and conservative way (TI 4).

"If they [students] haven't been taught any basic logic of debate and principle of critical thinking, how can they form deliberative online discussion rather than waste time on endless and useless quarrels?" (ті 3).

The two statements above indicate the degree of contrast that exists within the university in relation to students social-media-based civic learning. Such a debate can be linked to the question of whether a loose and flexible online community can facilitate an effective civic learning result (Livingstone, Bober, \& Helsper, 2005) and whether a guide from professional educators is necessary. 


\section{$5 \quad$ Reflective Cybercivic Learning: an Integrating Paradigm}

Based on dutiful (DCL) and actualising (ACL) paradigms, this study develops the third paradigm, reflective cybercivic learning $(R C L)$, which integrates the above two paradigms. This requires young people to become both informed and interested citizens, being willing and able to be involved in the processes of change-making. The most essential feature of RCL is the ability to keep critical thinking and take responsible action so that young people make positive contributions to their online and offline communities. Although such a level of cybercivic learning seems over-idealistic, several examples show such a possibility for students to bridge online and offline practices, official and unofficial knowledge, and informal and formal civic learning.

\subsection{Reflecting and Improving Announcements}

In the RCL paradigm, students try to further understand or question the authoritative materials, finding a way to improve, correct or reproduce the announcements if it is necessary. For example, the study observed that students on a bottom-up online forum reflect on rules and netiquettes provided by the forum administrative team and corrected impertinent expressions. As some expressions in the original post seem too offensive, the following commentators keep questioning and requiring the "Banzhu" [版主] who plays a role of board moderator, to correct the announcement of netiquettes. Some users disagreed with the subjective and arbitrary judgement on others so they reminded Banzhu to announce netiquettes in a respectful way. Others felt very uncomfortable about the use of a gender-discriminative metaphor of "Pofu" [泼妇] in the original post to describe a person quarrelling with others online, which is a linguistic stereotype portraying a fierce and irritated woman like a shrew. The gendered references and provocative words in the original post struck students as surprising and indicated a less developed public discussion concerning the respectful values of civic life. However, a promising result is that Banzhu finally apologised for the problem and improved the netiquettes, although this learning process took a bit long time.

The changes made to the online announcements show RCL can be collaborative, as students successfully communicated and transferred the right style of presenting civic values, namely to deliver ethics and moralities in an ethical and moral way.

\subsection{Constructing Online Intellectual Communities}

The RCL can also organise and integrate fragmental knowledge that students encountered in ACL to construct intellectual communities. There are two 
examples to further explain the possibility of RCL beyond ACL. One is provided by a student interviewee, who reflected his role as a digital citizen, calling himself "an information porter" instead of "a producer of knowledge". He also tried to clarify to what extent his online consumption can become civic participation.

The only thing that I did online that can be recognised as civic participation is that I donated to Wikipedia RMB 50 Yuan every year. I think the contributors of Wikipedia deserve my respect as they make tiny questions for research and provide knowledge-based answers in academic style with references (SI 23).

The student also pointed out that to build an online intellectual community needs "rational spirit", "professional research-based perspective", and "reciprocal collaboration" (SI 23).

The other example is drawn from observations between December 2012 and January 2013 on Renren and ChickenRun, showing how an individual life puzzle of purchasing train tickets before Chinese New Year became a civic concern discussed among student networks. The process of discussion can be summarised as below:

- A student complained about her difficulty of buying a ticket on her Renren profile.

- Other students responded to her and shared similar difficulties and successful purchasing experiences with practical strategies;

- A student studying Mathematics calculated different probabilities of getting a ticket under the current ticket allocation system, responding to the original post and also posted his findings on ChickenRun.

- Several students studying Management analysed the problems of the ticket sale system, such as complicated purchasing procedures, limited numbers of trains, unequal allocation, the monopoly by some companies and individuals for extra profit making.

- Students found that the newly launched online ticket-buying system not suitable for rural migrant workers who are not able to use online tools.

- Students called for setting up a volunteering group to help rural migrant workers purchase train tickets via a telephone sale system.

- Students made suggestions for policy change in rail transportation.

The discussion above presents the potential of a deliberative and democratic debate which includes an active discussion of problems, conflicts, claims of need and problem-solving strategies (Yang, 2009). Students made 
contributions based on their professional knowledge and skills; addressed the problem of digital divide, and tried to help migrant workers, a digitally and socioeconomically disadvantaged group. The most remarkable thing is that they sought possible critical-thinking and problem-solving approaches under the current policy framework. In short, this case shows the forming of an online intellectual community where young people work together and mutually support each other. This also indicates the possibility of social media to be used as social glue uniting people from different backgrounds together (Sunstein, 2001), although student discussions have not been observed to impact policymaking.

\subsection{Learning for Power Shifts between Online and Offline}

The idealist aim of the RCL paradigm is to empower students both in virtual and real communities. Although this is never easy, a few examples in this study have presented such a possibility that students transferring their civic capabilities and learning for power shifts between online and offline settings.

Interviewed students mentioned that they have collaboratively learned civic skills when integrating online and offline activities, especially when they successfully informed their peer groups to take actions. One student posted on ChickenRun about the problem of slippery floors in university public bathrooms, which often made students fall down and get hurt. Her post along with many replies were widely forwarded by students and eventually noticed by the university administrators.

Someone working at public-service sectors replied to our posts and solve this problem with non-slip mats put in place. This is the first time that I know who [which sector] is responsible for student welfare and how to communicate with them (sI 6).

In the process, students not only learned basic information about the university public-service system but also different communication skills with administrators. By integrating online and offline strategies their appeals got a satisfactory solution.

Another example is provided by a student (SI 2) who used to work in an environmental protection society at her university. The society initiated an offline campaign called 'One hour for the Earth' on 22 April (The Earth Day), calling for energy-saving actions among students. The society members publicised relevant information and knowledge online in support of the campaign, such as the origin of The Earth Day, statistic reports about energy consumption 
all over the world, the university's current energy consumption. The student reported that:

We published posts on ChickenRun, Renren and Weibo, encouraging students to turn off all of the lights from 8:00 pm to 9:00 pm on 22 April in the campus. When we saw the whole campus became dark in that one hour, I knew we got a great success (SI 2).

Although the influence of one single campaign is limited, student participants have been aware of the worldwide problem of energy-wasting, learning not only environment knowledge but also campaigning skills. The society members have also realised their ability to transfer online civic publicity into offline civic activities. In the process, they have also developed skills of criticalthinking and problem-solving. Additionally, they have become accomplished communicators, negotiators and campaign leaders.

The above examples of RCL illustrate the relationship between institutional and lifestyle civic learning both online and offline. This paradigm addresses students' ability to reflect for responsible actions, which leads to broadening awareness of civic values, such as international understanding, justice and tolerance, freedom of expression, individual rights, and social responsibility.

\section{Conclusion: Education for Digital and Cyber Citizenship}

In conclusion, this article so far showcases the potential of learning through civic participation in the wider community constructed by social media. Based on first-hand data drawn from qualitative research, it develops a framework of cybercivic learning including three paradigms, namely dutiful, actualising and reflective cybercivic learning. The characteristics and key elements of each learning approach can be summarised in Table 3 .

The working model of cybercivic learning has revealed a trend of learning innovation in citizenship education. Bennett et al. (2009) have argued that the challenges arise from technological changes along with social and political shifts require students to acquire civic knowledge, skills and values both from the digitally-living world and from the inputs of formal education. In order to cope with such challenges, the study articulates key recommendations to improve each paradigm of cybercivic learning.

Firstly, the dutiful cybercivic learning implies the task of nurturing "good cyber citizens" who prefer to respect authoritative or traditional values, acquire 
TABLE 3 Paradigms of Cybercivic Learning for University Students

\begin{tabular}{|c|c|c|c|}
\hline Paradigms & Topics/Knowledge & $\begin{array}{l}\text { Learning } \\
\text { Methods }\end{array}$ & Learning Outcomes \\
\hline $\begin{array}{l}\text { Dutiful } \\
\text { Cybercivic } \\
\text { Learning }\end{array}$ & $\begin{array}{l}\text { - public policy } \\
\text { - government } \\
\text { - party } \\
\text { - voting } \\
\text { - } \text { state legal system } \\
\text { - } \text { moral duty } \\
\text { - historical events } \\
\text { - cultural issues } \\
\text { - laws, rules and } \\
\quad \text { regulation }\end{array}$ & $\begin{aligned} \text { - } & \text { lurking } \\
\text { - } & \text { mainstreamed } \\
& \text { news feeding } \\
\text { - } & \text { announcement- } \\
& \text { reading } \\
\text { - } & \text { online civic } \\
& \text { courses }\end{aligned}$ & $\begin{array}{l}\text { - institutional knowledge } \\
\text { - } \text { rationality } \\
\text { - } \text { respect } \\
\text { - } \text { obedience } \\
\text { - } \text { responsibility }\end{array}$ \\
\hline $\begin{array}{l}\text { Actualising } \\
\text { Cybercivic } \\
\text { Learning }\end{array}$ & $\begin{array}{l}\text { - entertainment } \\
\text { - job-hunting } \\
\text { - shopping } \\
\text { - examination tips } \\
\text { - volunteering } \\
\text { - charity } \\
\text { - political consuming } \\
\text { - celebrity politics } \\
\text { - environmental } \\
\text { movements }\end{array}$ & $\begin{array}{l}\text { - lurking } \\
\text { - information } \\
\text { sharing } \\
\text { - lifestyle } \\
\text { political } \\
\text { discussing }\end{array}$ & $\begin{array}{l}\text { - informal civic knowledge } \\
\text { - civic interests } \\
\text { - self-expression } \\
\text { - freedom of speech } \\
\text { - reciprocity } \\
\text { - tolerance }\end{array}$ \\
\hline $\begin{array}{l}\text { Reflective } \\
\text { Cybercivic } \\
\text { Learning }\end{array}$ & $\begin{array}{l}\text { - } \text { institutional } \\
\text { knowledge } \\
\text { - life-style knowledge } \\
\text { - professional } \\
\text { knowledge } \\
\text { - collaborative } \\
\text { knowledge }\end{array}$ & 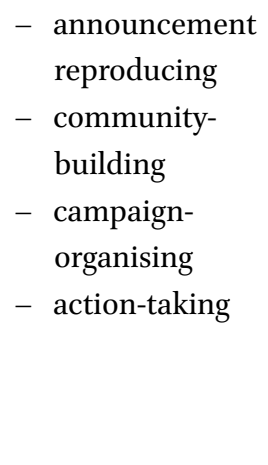 & $\begin{array}{l}\text { - } \text { constructed civic } \\
\text { knowledge } \\
\text { - } \text { critical thinking } \\
\text { - deliberative debating } \\
\text { - } \text { problem-solving } \\
\text { - decision-making } \\
\text { - negotiation } \\
\text { - } \text { mutual support } \\
\text { - community involvement } \\
\text { - } \text { ethics of participation }\end{array}$ \\
\hline
\end{tabular}


institutional civic knowledge, and responsibly serve both online and offline communities. This is a particularly important educational aim in China where patriotism and Socialist citizenship are advocated, and citizens are encouraged to take orderly civic participation in the field of mainstreamed politics. However, the dutiful paradigm can be fulfilled with participatory learning (Ito et al., 2013; Jenkins, Ito, \& boyd, 2015), so that students are willing to take part in structured institutional civic activities.

Secondly, the actualising cybercivic learning implies the task of nurturing "interested cyber citizens" who have basic awareness and informal knowledge of civic participation, pursuing civic rights and contributing to their communities through life-style activities, such as consumption, entertainment and environmental protection. In the Chinese context, the potential of such kind of cultural citizenship (Burgess, Foth, \& Klaebe, 2006) has not been valued in the formal curriculum. It is therefore the actualising paradigm should be applied to enrich citizenship education and to encourage learners' self-expression and peer-interaction, and to increase youth autonomy and creativity in civic participation and learning (Buckingham, 2003).

Thirdly, integrating and improving the two above paradigms, the reflective cybercivic learning aims to nurture "active responsible cyber citizens" who possess capabilities of critical thinking and power shifting between online and offline settings. The reflective paradigm should be emphasised for the innovation of citizenship education which enables young people to continually acquire constructed knowledge, instead of sticking to stereotypes or fragmented information through digital media. It focuses on empowering young people with problem-solving skills so that they can understand and deal with online and offline civic issues in more professional, deliberative and collaborative ways (Rheingold, 2012; Ito et al., 2013). Moreover, it should also pay more attention to fundamental good values, ethics and moralities to define the core of cyber citizenship.

As the framework integrates world-wide theoretical resources and empirical findings in China, it is expected to be applied in future for improving citizenship education at the university level to nurture responsible, reciprocal and reflective citizens, though different countries and contexts may need some localised adjustments. In addition, future studies need to consider new forms of social media along with innovated paradigms cybercivic learning. Last but not least, the study never advocates that cybercivic learning would completely replace the institutional citizenship programmes in higher education. Rather, the working framework of cybercivic learning needs more specific designs for different pedagogical purposes. 


\section{References}

Arthur, J., Davies, I., \& Hahn, C. (Eds.). (2008). The SAGE Handbook of Education for Citizenship and Democracy. London: SAge Publications.

Bachen, C., Raphael, C., Lynn, K.-M., McKee, K., \& Philippi, J. (2008). Civic Engagement, Pedagogy, and Information Technology on Web Sites for Youth. Political Communication, 25(3), 290-310.

Banaji, S., \& Buckingham, D. (2010). Young People, the Internet, and Civic Participation: An Overview of Key Findings from the CivicWeb Project. International Journal of Learning and Media, 2(1), 1-10.

Bennett, W. L. (2008a). Changing Citizenship in the Digital Age. In W. L. Bennett (Ed.), Civic Life Online: Learning How Digital Media Can Engage Youth (pp. 1-24). Cambridge, MA: The MIT Press.

Bennett, W. L. (Ed.) (2008b). Civic Life Online: Learning How Digital Media Can Engage Youth. Cambridge, Massachusetts: The Miт Press.

Bennett, W. L., Bers, M. U., Coleman, S., Earl, J., Foot, K., Levine, P., ... Xenos, M. (2006). MacArthur Online Discussions on Civic Engagement. Retrieved from http://spotlight .macfound.org/resources/Civic_Engagement-Online_Discussions'o6.pdf

Bennett, W. L., Freelon, D., \& Wells, C. (2010). Changing Citizen Identity and the Rise of a Participatory Media Culture. In L. R. Sherrod, J. Torney-Purta, \& C. Flanagan(Eds.), Handbook of Research on Civic Engagement in Youth (pp. 393-423). Hoboken, New Jersey: John Wiley \& Sons, Inc.

Bennett, W. L., Wells, C., \& Rank, A. (2009). Young Citizens and Civic Learning: Two paradigms of citizenship in the digital age. Citizenship Studies, 13(2), 105-120.

Blunkett, D., \& Taylor, M. (2010). Active Citizenship and Labour. In B. Crick \& A. Lockyer (Eds.), Active Citizenship: What Could it Achieve and How? (pp. 26-38). Edinburgh: Edinburgh University Press.

Buckingham, D. (2003). Media Education: Literacy, Learning and Contemporary Culture. Cambridge, UK: Polity Press.

Burgess, J., Foth, M., \& Klaebe, H. (2006). Everyday Creativity as Civic Engagement: A Cultural Citizenship View of New Media. Paper presented at the Communications Policy \& Research Forum, Sydney.

Chen, L. (2015). 网络社会青年公民意识的发生与引导 [Discovering and Guiding Youth Civic Awareness in Cyber Society]. Beijing, China: China Social Sciences Press.

Coleman, S. (2008). Doing IT for Themselves: Management versus Autonomy in Youth E-Citizenship. In W. L. Bennett (Ed.), Civic Life Online: Learning How Digital Media Can Engage Youth (pp. 189-206). Cambridge, MA: The MIт Press.

Crick, B., \& Lockyer, A. (Eds.). (2010). Active Citizenship: What Could it Achieve and How? Edinburgh: Edinburgh University Press. 
Dong, S., \& Han, H. (2008). 中国的互联网与网民 [China 's Internet and Users]. Beijing: New World Press.

Fang, Z. (2011). 大学生网络政治参与：现状分析与探讨 [University Students' Online Political Participation: current situation and discussion]. China Youth Study (3), $11-16,63$.

Giddens, A. (1991). Modernity and Self-Identity: Self and Society in the Late Modern Age. Cambridge: Polity Press.

Habermas, J. (1974 [1964]). The Public Sphere: An Encyclopaedia Article. New German Critique, 3, 49-55.

Hine, C. (2000). Virtual Ethnography. London: Sage.

Hudson, A. (2005). Citizenship Education and Students' Identities: A school-based action research project. In A. Osler (Ed.), Teachers, Human Rights and Diversity: Educating Citizens in Multicultural Societies. Stoke-on-Trent: Trentham.

Ireland, E., Kerr, D., Lopes, J., Nelson, J., \& Cleaver, E. (2006). Active Citizenship and Young People: Opportunities, Experiences and Challenges In and Beyond School Citizenship Education Longitudinal Study: Fourth Annual Report (DfES Research Report 732). Retrieved from London: http://publications.education.gov.uk/eOrdering Download/RR732.pdf.

Ito, M., Baumer, S., Bittanti, M., boyd, d., Cody, R., Herr-Stephenson, B., ... Tripp, L. (2010). Hanging Out, Messing Around, and Geeking Out : Kids Living and Learning with New Media. Cambridge; Mass; London: MIT Press.

Ito, M., Gutiérrez, K., Livingstone, S., Penuel, B., Rhodes, J., Salen, K., ... Watkins, S. C. (2013). Connected Learning: An Agenda for Research and Design. Retrieved from Irvine, CA: www.dmlhub.net/publications.

Jenkins, H., Ito, M., \& boyd, d. M. (2015). Participatory Culture in a Networked Era. Cambridge, UK: Polity Press.

Langmia, K., Tyree, T. C. M., O’Brien, P., \& Sturgis, I. (Eds.). (2014). Social Media: Pedagogy and Practice. Lanham, Maryland: University Press of America.

Lee, W. O., \& Ho, H.-h. (2008). Citizenship Education in China: Changing Concepts, Approaches and Policies in the Changing Political, Economic and Social Context. In J. Arthur, I. Davies, \& C. Hahn (Eds.), The SAGE Handbook of Education for Citizenship and Democracy (pp. 139-157). London: SAGE Publications.

Lin, K., \& Starkey, H. (2014). Active Citizens, Good Citizens and Insouciant Bystanders: the educational implications of Chinese university students'civic participation via social networking. London Review of Education, 12(1), 50-62.

Livingstone, S., Bober, M., \& Helsper, E. (2005). Active Participation or Just More Information? Young People's Take-up of Opportunities to Act and Interact on the Internet. Information, Communication \& Society, 8(3), 287-314. Retrieved from http:// eprints.lse.ac.uk/archive/ooooo396. 
Loader, B. D. (Ed.) (2007). Young Citizens in The Digital Age: Political Engagement, Young People and New Media. London, UK: Routledge.

Loader, B. D., Vromen, A., \& Xenos, M. A. (2014). The networked young citizen: social media, political participation and civic engagement. Information, Communication \& Society, 17(2), 143-150. Retrieved from http://dx.doi.org/10.1080/1369118X.2013.871571.

MOEPRC. (2010). Outline of China's National Plan for Medium and Long-term Education Reform and Development 2010-2020 [国家中长期教育改革和发展规划纲 要 2010-2020]. Retrieved from Beijing: http://www.herrank.com/her/en/newsde tail_55.html.

Osler, A. (Ed.) (200o). Citizenship and Democracy in Schools: Diversity, Identity, Equality. Stoke-on-Trent: Trentham.

Osler, A., \& Starkey, H. (2005). Changing Citizenship:Democracy and Inclusion in Education. Maidenhead: Open University Press.

Pateman, C. (1970). Participation and Democratic Theory. Cambridge: Cambridge University Press.

Pérez Expósito, L. (2013). Students'Representations of Political Participation: Implications for Citizenship Education in Mexico City's Secondary Schools. (PhD). Institute of Education, University of London, London.

Print, M., \& Tan, C. (Eds.). (2015). Educating "Good" Citizens in a Globalising World for the Twenty-First Century. Rotterdam: Sense Publishers.

Putnam, R. D. (2000). Bowling Alone: The Collapse and Revival of American Community. New York: Simon and Schuster.

QCA. (1998). Education for Citizenship and the Teaching of Democracy in Schools (The Crick Report). London: Qualification and Curriculum Authority.

Qi, X. (2011). 大学生网络政治参与状况实证研究 [An Empirical Study on University Students' Online Political Participation ]. 理论与改革 [Theory and Reform], $177(1), 153-155$.

Rheingold, H. (2012). Net Smart: How to Thrive Online. Cambridge, Massachusetts: The MIT Press.

Ribble, M. S., \& Bailey, G. D. (2011). Digital Citizenship in Schools (2nd edition). Washington, DC: International Society for Technology in Education.

Ross, A. (2008). Organizing a Curriculum for Active Citizenship Education. In J. Arthur, I. Davies, \& C. Hahn (Eds.), The SAGE Handbook of Education for Citizenship and Democracy (pp. 492-506). London: SAGE.

Selwyn, N. (2002). Literature Review in Citizenship, Technology and Learning. Retrieved from Futurelab: https://www.nfer.ac.uk/publications/FUTL65/FUTL65.pdf.

Sun, W. (2013). 网络与网络公民文化一一基于批判与建构的视角 [Internet and the Culture of Net Citizens_-_Based on A Critical and Constructive Perspective]. Beijing: China Social Sciences Press. 
Sunstein, C. (2001). Republic.com. Princeton: Princeton University Press.

Wells, C. (2015). The Civic Organization and the Digital Citizen: Communicating Engagement in a Networked Age. Oxford: Oxford University Press.

Yang, G. (2009). The Power of the Internet in China: Citizen Activism Online. New York: Columbia University Press. 